\title{
Challenges to Economic Growth in Latin America and the Caribbean: A Preliminary Exploration
}

\author{
Edmund M. Tavernier*
}

\begin{abstract}
A fixed-effects model is developed to analyze the relationship between economic growth and agricultural development, trade balances, exports, and investment in Latin America and the Caribbean. The empirical evidence indicates a positive relationship between exports as a percentage of GDP and economic growth in the region. The results also show that persistent trade imbalances and a significant debt burden serve as a drag on economic growth, but investment and exports do not. The findings allow preliminary inferences to be made about the challenges to economic growth in the region.
\end{abstract}

\section{INTRODUCTION}

The Asian financial crisis helped to focus significant attention on the role of Latin America and the Caribbean region, particularly Brazil, in reviving and sustaining healthy economic conditions around the world. That region has a population of 450 million and a GDP of approximately \$1.3 trillion (IDB 1998a). Because of its size and growth potential, the Latin American market holds significant opportunities for trade and investment. Over the past decade, the region experienced significant economic gains spurred on by an environment that is supportive of savings, investments, and growth through macroeconomic stability. This environment was facilitated by the removal of trade barriers, liberalized service polices, and the privatization of state enterprises (USTR 1997).

As a result of the above policy changes, gross domestic private investment grew at an annual rate of 8 percent between 1985 and 1995, and over that decade regional GDP growth increased by 2.3 percent per year while per capita income increased by 12 percent (Lora and Barrera 1997). Further, between 1989 and 1998 foreign direct investment increased from $\$ 7.4$ billion to $\$ 57.7$ billion (IDB 1998a). These statistics make Latin America and the Caribbean the fastest growing regional market for U.S. exports (Schaffer 1992). Since 1991, the U.S. has consistently run a trade surplus with Latin America and the Caribbean. Former U.S. President Bush (1992) suggests that strengthening the economies of Latin America would enhance U.S. exports.

Merchandise exports from the U.S. to Latin America and the Caribbean increased from $\$ 43.7$ billion to $\$ 142.4$ billion between 1988 and 1998 (USAID 2001). A significant proportion of this increase was exports to Brazil- $\$ 4.2$ billion to $\$ 15.2$ billion-during that period. Since the initiation of the Real Plan, the innovative

*Associate Professor, Department of Agriculture, Food and Resource Economics, Rutgers, The State University, New Brunswick, NJ. The author would like to thank two anonymous referees for their helpful comments and suggestions. 
stabilization program introduced in July 1994, and the liberalization of Brazil's trade regime, U.S. exports to Brazil have increased by 88 percent, at least until 1998. Brazil recorded an annual growth rate of 13.6 percent between 1988 and 1998, but experienced negative growth of 4.7 percent between 1997 and 1998 . Given its importance, the actions of former U.S. Treasury Secretary Robert E. Rubin and Federal Reserve Chairman Alan Greenspan to push "hard to build a $\$ 30$ billion firewall, funded by the IMF and private banks around Brazil" (McNamee et al. 1998, p. 36) is understandable. Brazil is the eighth largest economy in the world with a GDP of $\$ 532$ billion in 1998 and the largest economy in Latin America. The country is also the U.S.' largest trading partner in Latin America. Latin America also depends on exports as the "engine" of economic growth and has experienced significant increases in exports.

Between 1990 and 1998, exports from Latin America and the Caribbean increased by 111 percent (IDB 1999a). During that period, export statistics for all integration groupings in Latin America and the Caribbean were up significantly. Specifically, 1) exports from the Latin American Integration Association (ALADI) ${ }^{1}$ increased by 100 percent; 2) the Andean Community ${ }^{2}$ witnessed a 27 percent increase in its exports; 3 ) exports from the Central American Common Market $(\mathrm{CACM})^{3}$ increased by 205 percent; 4) the Caribbean Community and Common Market (CARICOM) ${ }^{4}$ had a 24 percent increase in exports; and 5) exports from the Group of Three (G-3) ${ }^{5}$, the Southern Common Market (MERCOSUR) ${ }^{6}$, and other countries in the Free Trade Area of the Americas (FTAA) ${ }^{7}$ increased by 124 percent, 77 percent, and 108 percent, respectively. ${ }^{8}$

Despite these successes, significant challenges to sustained economic growth remain in Latin America and the Caribbean. In Brazil, the substantial and permanent fiscal adjustment required under the Real Plan has not been achieved and, as a result, the overvalued exchange rate and high interest rates are increasingly unsustainable (IDB 1999b). ${ }^{9}$ These factors highlight the concerns of foreign investors, who drained $\$ 20$ billion of Brazil's currency reserves in September 1998 (Templeman 1998). Such capital flight and a public debt of $\$ 290$ billion may constrain long-term growth prospects in Brazil. Jeffrey Applegate (in Woolley 1998, p. 100) argued that "some kind of global debt swap package" between developed countries and emerging market economies would be crucial to reviving global

${ }^{1}$ Countries in the ALADI integration group include Argentina, Bolivia, Brazil, Chile, Colombia, Ecuador, Mexico, Paraguay, Peru, Uruguay, and Venezuela.

${ }^{2}$ Countries in the Andean Community include Bolivia, Colombia, Ecuador, Peru, and Venezuela.

${ }^{3}$ Countries in the CACM integration group include Costa Rica, El Salvador, Guatemala, Honduras, and Nicaragua.

${ }^{4}$ Countries in the CARICOM integration group include the Bahamas, Barbados, Belize, Guyana, Jamaica, Suriname, and Trinidad and Tobago. (Statistics for Antigua and Barbuda, Dominica, Grenada, Monsterrat, St. Kitts and Nevis, St. Lucia, St. Vincent, and the Grenadines are not available.)

${ }^{5}$ Countries in the G-3 integration group include Colombia, Mexico, and Venezuela.

${ }^{6}$ Countries in the MERCOSUR integration group include Argentina, Brazil, Paraguay, and Uruguay.

${ }^{7}$ Countries in the FTAA integration group include Chile, Dominican Republic, Haiti, and Panama.

${ }^{8}$ Statistics for the Organization of Eastern Caribbean States (OECS), which includes Antigua, Dominica, Grenada, St. Kitts and Nevis, St. Lucia, St. Vincent, and the Grenadines, are not available.

${ }^{9}$ On January 13, 1999, President Cardoso announced that Brazil would allow a controlled devaluation of the real.

After that announcement the real promptly fell by 8 percent. 
growth in 1999. Bernal (1995) suggests that servicing the external debt is one of the most challenging impediments to economic growth in Latin America and the Caribbean.

The implications of a long-term downturn in Brazil's economy are worrisome not only for the world economy but also for the economy of Latin America and the Caribbean. In 1995, for example, 54.2 percent of Brazil's $\$ 1.06$ billion in merchandise imports from ALADI came from Argentina. Brazil is Argentina's primary trading partner and a weak real hurts Argentine exporters and could potentially plunge that country into a recession. In the Andean Community, Brazil imported $\$ 894.9$ million, or 68.8 percent, from Venezuela during that period. Brazil's biggest trading partner in CARICOM is Trinidad and Tobago, from which it imported approximately $\$ 47$ million in 1995. In 1997, Trinidad and Tobago had an economic growth rate of 3.9 percent due primarily to increased value added in the construction, manufacturing, and wholesale and retail sectors. Mining and quarrying continued to decline and agriculture barely maintained its share of domestic output (Haque 1998).

In many CARICOM countries, bananas account for over 70 percent of external revenue. This revenue has eroded significantly under evolving rules for preferential access to the European Union (WBG 1998). Thus, the EU's $\$ 2$ billiona-year regime for the importation, sale, and distribution of bananas continues to be a major concern for policy makers and the agricultural community in the Caribbean. These countries have experienced large negative current account balances and, on average, had debt-to-GDP ratios of approximately 30 percent in the early 1990s.

It is clear from the above that, despite the successes enjoyed by Latin America and the Caribbean, lasting economic growth in the region is not assured. Among the concerns is the role of investments, trade, debt, and agricultural development in the region's economic growth. Understanding such a role in the context of the global economy is important for the design of public policies to soften the impact of economic downturns when they arise and for garnering support when new policies are to be implemented.

The remainder of the paper is organized as follows. In the next section the data used in the study are discussed. Section 3 presents key summary statistics from the data and discusses important trends that are evident in the data. Section 4 presents the econometric model and Section 5 presents the empirical results. The final section concludes with a brief summary and policy implications.

\section{DATA}

The primary data source for the analysis of challenges to economic growth in Latin America and the Caribbean is the web site of the Inter-American Development Bank (http:/ / www.iadb.org). The web site contains complete annual economic data for various countries in Latin America and the Caribbean for the period 1988 to 1996 . Data after 1996 are not available for all countries from the analysis. 
Data on trade balance (Tradebal) and current account balance (CurAcctBal) (in million of dollars) are taken from Balance of Payments; data on export (Exp), gross domestic investment (Invest) and agriculture (Agri) (as a percentage of GDP), and real per capita growth rates (Gdp), are taken from the National Accounts; and data on total external debt (Debt) and debt service ratio (Debtsvc) (as a percentage of GDP) are taken from the External Debt section on the web site.

\section{SUMMARY STATISTICS}

TABLE 1

Summary Statistics for Individual Countries, 1988-1996

\begin{tabular}{|c|c|c|c|c|c|c|c|c|}
\hline & $\begin{array}{l}\text { Agri } \\
(\%)\end{array}$ & $\begin{array}{l}\text { Debt } \\
(\%)\end{array}$ & $\begin{array}{c}\text { Debtsvc } \\
(\%)\end{array}$ & $\begin{array}{l}\text { Exp } \\
(\%)\end{array}$ & $\begin{array}{c}\text { Gdp } \\
(\%)\end{array}$ & $\begin{array}{c}\text { Invest } \\
(\%)\end{array}$ & $\begin{array}{c}\text { Tradebal } \\
\text { (\$millions) }\end{array}$ & $\begin{array}{l}\text { CurAcctBal } \\
\text { (\$millions) }\end{array}$ \\
\hline \multicolumn{9}{|l|}{ Argentina } \\
\hline average & 7.1 & 37.1 & 42.4 & 8.5 & 1.4 & 19.7 & $2,082.7$ & $-3,197.6$ \\
\hline minimum & 6.4 & 25.9 & 34.1 & 7.1 & -8.2 & 14.0 & $-4,238.0$ & $-10,117.0$ \\
\hline maximum & & 77.8 & 51.9 & 10.4 & 8.9 & 24.8 & $8,628.0$ & $4,552.0$ \\
\hline cV & 7.8 & 44.4 & 11.5 & 14.5 & 466.4 & 17.7 & 200.2 & -133.8 \\
\hline \multicolumn{9}{|l|}{ Barbados } \\
\hline average & $5: 8$ & 36.6 & 12.4 & 51.6 & 0.5 & 15.0 & -382.4 & 65.0 \\
\hline minimum & 5.2 & 29.1 & 8.1 & 49.4 & -5.3 & 8.9 & -456.2 & -23.5 \\
\hline maximum & 6.3 & 44.9 & 18.1 & 54.8 & 4.7 & 18.9 & -277.8 & 143.4 \\
\hline CV & 7.1 & 12.5 & 26.3 & 3.3 & 753.5 & 23.7 & -15.8 & 90.5 \\
\hline \multicolumn{9}{|l|}{ Belize } \\
\hline average & 22.3 & 40.5 & 10.0 & 61.8 & 3.6 & 27.2 & -75.8 & -19.2 \\
\hline minimum & 21.3 & 36.5 & 6.9 & 57.9 & -1.3 & 21.5 & -118.5 & -48.5 \\
\hline maximum & 24.1 & 46.7 & 14.4 & 65.8 & 10.2 & 31.6 & -41.8 & 15.4 \\
\hline $\begin{array}{c}\text { CV } \\
\text { Bolivia }\end{array}$ & 3.8 & 8.6 & 28.5 & 4.4 & 113.4 & 13.8 & -33.6 & -101.8 \\
\hline \multicolumn{9}{|l|}{ Bolivia } \\
\hline & 15.8 & 81.6 & 40.8 & 8.3 & 1.6 & 14.1 & -158.5 & -323.4 \\
\hline minimum & 13.3 & 71.5 & 28.6 & 13.9 & -0.8 & 11.1 & -432.4 & -533.9 \\
\hline maximum & 17.7 & 104.3 & 81.0 & 21.3 & 2.8 & 16.3 & 55.2 & -90.2 \\
\hline$\underset{\text { Brazil }}{\mathrm{Cv}}$ & 11.4 & 12.4 & 39.1 & 12.3 & 67.3 & 12.3 & -107.6 & -42.5 \\
\hline \multicolumn{9}{|l|}{ Brazil } \\
\hline $\begin{array}{l}\text { average } \\
\text { minimum }\end{array}$ & $\begin{array}{l}8.3 \\
81\end{array}$ & $\begin{array}{l}26.9 \\
18.3\end{array}$ & $\begin{array}{l}33.4 \\
21.7\end{array}$ & $\begin{array}{l}8.9 \\
8.0\end{array}$ & 0.2 & 20.2 & $\begin{array}{r}9,815.3 \\
5,5390\end{array}$ & $\begin{array}{r}-4,009.7 \\
-23,6020\end{array}$ \\
\hline maximum & 8.7 & 38.0 & 46.7 & 10.4 & 4.5 & 21.9 & $19,168.0$ & $\begin{array}{r}-0,0089.0 \\
6,089.0\end{array}$ \\
\hline cv & 2.6 & 21.8 & 30.5 & 10.1 & $1,615.5$ & 6.9 & 87.0 & -245.2 \\
\hline \multicolumn{9}{|l|}{ Chile } \\
\hline average & 8.9 & 52.7 & 27.0 & 25.9 & 6.3 & 28.2 & 799.9 & $-1,304.6$ \\
\hline minimum & 8.5 & 38.0 & 20.3 & 22.9 & 2.0 & 22.6 & $-1,094.0$ & $-3,742.0$ \\
\hline maximum & 9.3 & 81.1 & 35.1 & 28.0 & 10.4 & 34.9 & $2,210.0$ & -99.0 \\
\hline CV & 2.7 & 27.0 & 17.9 & 6.3 & 41.7 & 15.3 & 141.7 & -91.3 \\
\hline \multicolumn{9}{|l|}{ Colombia } \\
\hline average & 15.4 & 38.2 & $\begin{array}{l}43.0 \\
316\end{array}$ & 18.6 & 2.2 & 26.0 & -35.1 & \\
\hline $\begin{array}{l}\text { minimum } \\
\text { maximum }\end{array}$ & $\begin{array}{l}14.0 \\
16.6\end{array}$ & $\begin{array}{l}31.1 \\
43.4\end{array}$ & $\begin{array}{l}31.6 \\
53.3\end{array}$ & $\begin{array}{l}15.1 \\
20.8\end{array}$ & $\begin{array}{r}-0.3 \\
4.4\end{array}$ & $\begin{array}{l}16.7 \\
36.6\end{array}$ & $\begin{array}{r}-2,699.0 \\
2959.0\end{array}$ & $\begin{array}{r}-4,946.0 \\
23490\end{array}$ \\
\hline $\begin{array}{l}\text { maximum } \\
\mathrm{cv}\end{array}$ & 5.9 & 12.8 & 15.9 & 10.6 & 74.0 & 29.8 & $\begin{array}{r}2,959.0 \\
-6,112.0\end{array}$ & -202.3 \\
\hline \multicolumn{9}{|l|}{ Costa Rica } \\
\hline average & 15.7 & 60.2 & 19.8 & 37.5 & 1.2 & 26.8 & -411.6 & -284.1 \\
\hline minimum & 15.1 & 38.0 & 15.2 & 29.3 & -2.7 & 21.9 & -760.8 & -620.2 \\
\hline maximum & 16.4 & 92.1 & 26.5 & 46.7 & 4.9 & 31.7 & -97.9 & -75.2 \\
\hline cv. & 2.6 & 30.3 & 19.7 & 14.5 & 187.5 & 11.4 & -50.2 & -64.6 \\
\hline \multicolumn{9}{|c|}{ Dominican Republic } \\
\hline average & 14.5 & 48.5 & 12.5 & 35.3 & 1.3 & 27.9 & $-1,289.4$ & -275.4 \\
\hline minimum & 13.6 & 31.0 & 7.1 & 26.1 & -7.5 & 22.5 & $-1,611.8$ & -707.9 \\
\hline maximum & 15.4 & 69.9 & 18.1 & 62.3 & 6.1 & 34.6 & -718.3 & -18.9 \\
\hline cV & 4.3 & 24.9 & 35.3 & 43.4 & 318.0 & 14.1 & -24.8 & -73.2 \\
\hline \multicolumn{9}{|l|}{ Ecuador } \\
\hline average & 13.0 & 87.4 & 30.8 & 27.1 & 1.7 & 21.4 & 742.3 & -507.6 \\
\hline minimum & 12.6 & 75.7 & 21.8 & 23.6 & -3.0 & 16.1 & 354.0 & -735.0 \\
\hline maximum & 13.5 & 104.3 & 40.0 & 30.4 & 9.5 & 26.1 & $1,220.0$ & 111.0 \\
\hline CV & 2.6 & 12.7 & 21.0 & 9.4 & 198.2 & 15.1 & 37.3 & -61.4 \\
\hline \multicolumn{9}{|l|}{ El Salvador } \\
\hline & $\begin{array}{l}15.0 \\
13.6\end{array}$ & $\begin{array}{l}34.1 \\
27.0\end{array}$ & 13.8 & 15.4 & -0.7 & 13.9 & $\begin{array}{r}-918.0 \\
-1,523.2\end{array}$ & $\begin{array}{l}-123.8 \\
-322.2\end{array}$ \\
\hline $\begin{array}{l}\text { minimum } \\
\text { maximum }\end{array}$ & 17.1 & 40.9 & 39.4 & 24.0 & 5.0 & 22.4 & -355.9 & 25.8 \\
\hline CV & 9.9 & 18.2 & 32.8 & 15.0 & 92.7 & 16.4 & -38.6 & -82.6 \\
\hline
\end{tabular}

Note: Author's calculation from statistics compiled at http:/www.iadb.org. 
TABLE 1 (continued)

Summary Statistics for Individual Countries, 1988-1996

\begin{tabular}{|c|c|c|c|c|c|c|c|c|}
\hline & $\begin{array}{l}\text { Agri } \\
(\%)\end{array}$ & $\begin{array}{l}\text { Debt } \\
(\%)\end{array}$ & $\begin{array}{c}\text { Debtsvc } \\
(\%)\end{array}$ & $\begin{array}{l}\text { Exp } \\
(\%)\end{array}$ & $\begin{array}{l}\text { Gdp } \\
(\%)\end{array}$ & $\begin{array}{c}\text { Invest } \\
(\%)\end{array}$ & $\begin{array}{c}\text { Tradebal } \\
\text { (\$millions) }\end{array}$ & $\begin{array}{l}\text { CurAcctBal } \\
\text { (\$millions) }\end{array}$ \\
\hline \multicolumn{9}{|l|}{ Guatemala } \\
\hline average & 25.1 & 28.6 & 18.2 & 19.7 & 1.3 & 16.0 & -659.7 & -470.5 \\
\hline minimum & 24.1 & 23.3 & 12.3 & 17.7 & 0.3 & 13.6 & $-1,044.1$ & -705.9 \\
\hline maximum & 25.9 & 37.5 & 29.4 & 22.4 & 2.2 & 18.9 & -216.6 & -183.7 \\
\hline $\mathrm{cv}$ & 2.8 & 15.5 & 36.7 & 7.3 & 49.9 & 11.4 & -50.1 & -41.6 \\
\hline \multicolumn{9}{|l|}{ Guyana } \\
\hline average & 41.3 & 410.7 & 46.3 & 77.4 & 2.9 & 29.6 & -21.2 & -118.2 \\
\hline minimum & 38.1 & 221.6 & 14.7 & 61.2 & -8.1 & 18.3 & -68.3 & -149.6 \\
\hline maximum & 43.0 & 567.6 & 150.5 & 93.6 & 11.7 & 42.3 & 18.6 & -50.0 \\
\hline $\mathrm{cv}$ & 3.8 & 24.9 & 109.9 & 14.0 & 243.4 & 21.5 & -157.6 & -25.9 \\
\hline \multicolumn{9}{|l|}{ Haiti } \\
\hline average & 36.9 & 37.9 & 20.6 & 12.9 & -5.3 & 6.8 & -184.1 & -42.2 \\
\hline minimum & 33.3 & 30.5 & 3.2 & 8.8 & -16.5 & 1.6 & -379.9 & -77.5 \\
\hline maximum & 43.7 & 48.2 & 60.8 & 15.5 & 2.3 & 12.2 & -89.7 & 5.3 \\
\hline $\mathrm{cv}$ & 10.0 & 20.5 & 93.3 & 19.5 & -111.0 & 69.2 & -58.4 & -62.1 \\
\hline \multicolumn{9}{|l|}{ Honduras } \\
\hline average & 22.2 & 102.8 & 32.7 & 31.4 & 0.4 & 28.7 & -116.1 & -200.8 \\
\hline minimum & 21.1 & 62.2 & 17.9 & 27.5 & -4.1 & 22.2 & -257.4 & -351.5 \\
\hline maximum & 23.4 & 127.3 & 49.0 & 33.4 & 3.1 & 37.0 & -11.8 & -51.4 \\
\hline $\mathrm{cv}$ & 3.4 & 21.7 & 25.5 & 6.2 & 630.4 & 18.0 & -74.2 & -48.2 \\
\hline \multicolumn{9}{|l|}{ Jamaica } \\
\hline average & 7.4 & 102.5 & 29.1 & 58.6 & 1.6 & 28.3 & -605.6 & -150.7 \\
\hline minimum & 6.1 & 66.8 & 20.8 & 49.9 & -2.1 & 25.8 & -994.2 & -312.1 \\
\hline maximum & 8.7 & 126.7 & 43.7 & 69.4 & 6.4 & 36.5 & -356.9 & 47.5 \\
\hline $\mathrm{cv}$ & 12.6 & 18.9 & 27.0 & 10.5 & 164.9 & 11.6 & -36.8 & -93.0 \\
\hline \multicolumn{9}{|l|}{ Mexico } \\
\hline average & 7.6 & 41.6 & 34.8 & 21.7 & 0.4 & 23.8 & $-4,378.1$ & $-12,438.7$ \\
\hline minimum & 7.2 & 30.8 & 23.2 & 18.3 & -8.1 & 18.8 & $-18,464.0$ & $-29,662.0$ \\
\hline maximum & 8.2 & 58.0 & 44.9 & 33.0 & 3.7 & 28.0 & $7,089.0$ & $-1,576.0$ \\
\hline cv & 3.9 & 23.4 & 20.7 & 25.7 & $1,136.7$ & 12.3 & -222.3 & -87.9 \\
\hline \multicolumn{9}{|l|}{ Nicaragua } \\
\hline average & 31.1 & 588.7 & 48.3 & 23.1 & -2.5 & 25.1 & -380.1 & -513.6 \\
\hline minimum & 28.2 & 276.7 & 3.3 & 14.1 & -14.2 & 19.3 & -547.7 & -769.0 \\
\hline maximum & 33.7 & 1176.6 & 198.8 & 35.9 & 2.6 & 35.5 & -228.6 & -264.2 \\
\hline $\mathrm{cv}$ & 5.6 & 45.3 & 124.3 & 26.6 & -198.5 & 21.9 & -27.5 & -35.6 \\
\hline \multicolumn{9}{|l|}{ Panama } \\
\hline average & 8.8 & 90.4 & 6.4 & 81.3 & 0.9 & 21.0 & -298.8 & 2.4 \\
\hline minimum & 8.1 & 70.0 & 0.4 & 69.3 & -14.8 & 6.1 & -629.8 & -343.0 \\
\hline maximum & 10.1 & 117.6 & 15.3 & 106.8 & 6.9 & 32.3 & 156.8 & 721.7 \\
\hline $\mathrm{cv}$ & 8.7 & 20.9 & 77.7 & 14.0 & 783.3 & 43.7 & -80.6 & $13,246.3$ \\
\hline \multicolumn{9}{|l|}{ Paraguay } \\
\hline average & 27.0 & 31.0 & 15.1 & 34.4 & 0.6 & 22.2 & -766.2 & -352.0 \\
\hline minimum & 25.9 & 22.1 & 6.0 & 25.1 & -1.5 & 20.6 & $-1,440.8$ & -637.4 \\
\hline maximum & 28.0 & 52.8 & 34.0 & 46.0 & 3.1 & 24.0 & 164.1 & 255.6 \\
\hline cv & 2.4 & 32.7 & 72.4 & 21.9 & 259.2 & 4.3 & -75.4 & -80.2 \\
\hline \multicolumn{9}{|l|}{ Peru } \\
\hline average & 7.1 & 43.6 & 26.3 & 12.0 & -1.2 & 23.6 & -530.7 & $-2,253.4$ \\
\hline minimum & 6.7 & 35.5 & 9.7 & 9.1 & -14.7 & 19.5 & $-2,168.0$ & $-4,314.0$ \\
\hline maximum & 7.4 & 48.4 & 73.8 & 13.6 & 12.0 & 29.7 & $1,246.0$ & -570.0 \\
\hline $\mathrm{cv}$ & 3.2 & 8.9 & 76.1 & 10.4 & -680.2 & 14.9 & -203.7 & -51.2 \\
\hline \multicolumn{9}{|c|}{ Trinidad \& Tobago } \\
\hline average & 2.5 & 47.5 & 23.2 & 48.5 & -0.4 & 13.1 & 592.8 & 117.0 \\
\hline minimum & 2.0 & 39.4 & 13.5 & 39.9 & -5.3 & 10.6 & 275.7 & -88.6 \\
\hline maximum & 2.8 & 51.4 & 37.8 & 56.2 & 3.2 & 15.4 & $1,012.5$ & 459.0 \\
\hline cv & 9.7 & 7.7 & 32.4 & 11.6 & -720.2 & 12.1 & 35.5 & 155.2 \\
\hline
\end{tabular}

Note: Author's calculation from statistics compiled at http:/www.iadb.org. 
TABLE 1 (continued)

Summary Statistics for Individual Countries, 1988-1996

\begin{tabular}{|c|c|c|c|c|c|c|c|c|}
\hline & $\begin{array}{l}\text { Agri } \\
(\%)\end{array}$ & $\begin{array}{l}\text { Debt } \\
(\%)\end{array}$ & $\begin{array}{c}\text { Debtsvc } \\
\text { (\%) }\end{array}$ & $\begin{array}{l}\text { Exp } \\
\text { (\%) }\end{array}$ & $\begin{array}{l}\text { Gdp } \\
(\%)\end{array}$ & $\begin{array}{c}\text { Invest } \\
(\%)\end{array}$ & $\begin{array}{c}\text { Tradebal } \\
\text { (\$millions) }\end{array}$ & $\begin{array}{l}\text { CurAcctBal } \\
\text { (\$millions) }\end{array}$ \\
\hline \multicolumn{9}{|l|}{ Uruguay } \\
\hline average & 11.4 & 40.6 & 30.0 & 26.5 & 2.3 & 14.1 & -135.8 & -83.7 \\
\hline minimum & 10.9 & 29.5 & 17.3 & 21.2 & -2.3 & 11.0 & -706.0 & -438.3 \\
\hline maximum & 12.1 & 55.7 & 50.8 & 31.2 & 7.2 & 16.2 & 462.8 & 185.9 \\
\hline & 3.1 & 24.8 & 40.6 & 12.2 & 135.4 & 13.8 & -346.4 & -247.5 \\
\hline \multirow{5}{*}{$\begin{array}{l}\text { Venezuela } \\
\text { average } \\
\text { minimum } \\
\text { maximum } \\
\mathrm{cv}\end{array}$} & & & & & & & & \\
\hline & 5.2 & 60.9 & 29.9 & 31.2 & 0.2 & 17.3 & $5,823.2$ & $1,566.0$ \\
\hline & 4.8 & 46.0 & 18.7 & 25.8 & -10.8 & 10.2 & $-1,863.0$ & $-5,809.0$ \\
\hline & 5.9 & 75.6 & 50.2 & 37.3 & 7.5 & 25.7 & $13,756.0$ & $8,914.0$ \\
\hline & 7.9 & 14.7 & 38.8 & 11.5 & $3,483.9$ & 29.4 & 81.0 & 316.0 \\
\hline
\end{tabular}

Note: Author's calculation from statistics compiled at http:/www.iadb.org.

Table 1 presents summary statistics by country for the period 1988 to 1996. The statistics are presented to facilitate country-to-country comparisons and include the coefficient of variation (CV), mean, and minimum and maximum values. The $C V$ measures the dispersion around the mean of the variables and is used as a measure of variability in variables among countries. For example, in the case of agriculture as a percentage of GDP, Paraguay has the smallest variability (2.4 percent), while Jamaica has the greatest variability (12.6 percent). In absolute terms, for all the countries examined the variability in agriculture as a percentage of GDP was the smallest, suggesting very little variation in agriculture's contribution to the rate of growth. In 10 of the 24 countries examined, the contribution of agriculture as a percentage of GDP was less than 10 percent, an indication of the diminished reliance on the agricultural sector as an engine of growth in that region. The lowest and highest contribution of agriculture as a percentage of GDP were 2 percent and 43.7 percent, for Trinidad and Tobago and Haiti, respectively.

The variability in debt as a percentage of GDP ranges from 45.3 percent for Nicaragua to 7.7 percent for Trinidad and Tobago. In 13 countries, the variability in debt as a percentage of GDP is over 20 percent. In only three countries is the variability in debt as a percentage of GDP less than 10 percent. However, a small variability in debt as a percentage of GDP does not imply that a country is less heavily indebted than other countries, but that the scatter or dispersion around the mean is less. For example, although the variability in debt as a percentage of GDP is low for Trinidad and Tobago, the average debt as a percentage of GDP for that country is approximately 1.8 times greater than that of Brazil, which has a CV of approximately three times that of Trinidad and Tobago. The variability in debt service ratio as a percentage of GDP ranges from 11.5 percent for Argentina to 124.3 percent for Nicaragua and is generally larger than the variability in debt as a percentage of GDP. Twenty countries had variability in debt service ratio as a percentage of GDP of over 20 percent. Nicaragua had the highest debt service ratio as a percentage of GDP of 198.8 percent, while Panama had the lowest with 0.4 percent.

The contribution of exports to regional growth is relatively stable. During the period 1988 to 1996, the variability in exports as a percentage of GDP ranged from 3.3 to 43.4 percent. Only four countries had a variability of over 20 percent 
in exports as a percentage of GDP. Average exports as a percentage of GDP ranged from 8.3 percent for Bolivia to 81.3 percent for Panama.

Table 1 also indicates that Latin America and the Caribbean had widely divergent economic growth rates. The average GDP ranges from -5.3 percent for Haiti to 6.3 percent for Chile. Guatemala and Chile are the only two countries that did not experience negative growth rates during 1988-1996. During that period, in absolute terms, the variability in growth ranged from 41.7 percent (Chile) to $3,483.9$ percent (Venezuela). The negative and persistent trade balances may have served to dampen growth while the relatively low gross domestic investment rates provided little countervailing influence.

TABLE 2

Summary of Socioeconomic Variables Used in Analysis, 1988-1996

\begin{tabular}{|c|c|c|c|c|c|c|c|c|c|}
\hline & 1988 & 1989 & 1990 & 1991 & 1992 & 1993 & 1994 & 1995 & 1996 \\
\hline \multicolumn{10}{|l|}{ Agri (\%) } \\
\hline average & 15.6 & 15.7 & 15.7 & 15.7 & 15.9 & 15.6 & 15.6 & 15.5 & 15.6 \\
\hline minimum & 2.0 & 2.2 & 2.5 & 2.5 & 2.5 & 2.8 & 2.7 & 2.5 & 2.5 \\
\hline maximum & 41.0 & 41.2 & 38.1 & 39.6 & 43.0 & 41.6 & 43.7 & 42.9 & 42.1 \\
\hline \multicolumn{5}{|l|}{ Debt (\%) } & & & & & 68.6 \\
\hline average & 127.6 & 109.8 & 90.9 & 96.5 & 90.5 & 84.3 & 83.0 & 75.9 & 62.3 \\
\hline minimum & 32.3 & 26.9 & 24.0 & 18.3 & 24.9 & 22.8 & 25.0 & 22.6 & 22.1 \\
\hline maximum & 1176.6 & 842.1 & 475.0 & 567.6 & 528.4 & 499.0 & 546.0 & 470.8 & 276.7 \\
\hline cV & 189.8 & 160.8 & 122.5 & 150.3 & 146.8 & 140.7 & 145.3 & 136.0 & 99.6 \\
\hline \multicolumn{10}{|l|}{ Debtsvc (\%) } \\
\hline $\begin{array}{l}\text { average } \\
\text { minimum }\end{array}$ & $\begin{array}{r}31.5 \\
0.8\end{array}$ & $\begin{array}{r}30.2 \\
0.4\end{array}$ & $\begin{array}{r}28.5 \\
4.0\end{array}$ & $\begin{array}{r}32.7 \\
62\end{array}$ & $\begin{array}{r}25.4 \\
36\end{array}$ & 25.8 & 24.9 & 23.4 & $\begin{array}{r}23.7 \\
64\end{array}$ \\
\hline maximum & $\begin{array}{r}0.0 \\
81.0\end{array}$ & $\begin{array}{r}0.4 \\
150.5\end{array}$ & $\begin{array}{r}4.0 \\
117.6\end{array}$ & $\begin{array}{r}6.2 \\
198.8\end{array}$ & $\begin{array}{r}3.6 \\
43.3\end{array}$ & 73.8 & $\begin{array}{r}5.2 \\
60.8\end{array}$ & $\begin{array}{r}4.9 \\
44.5\end{array}$ & $\begin{array}{r}6.4 \\
51.9\end{array}$ \\
\hline cv & 57.4 & 97.1 & 81.9 & 113.4 & 40.0 & 63.2 & 59.8 & 51.7 & 56.2 \\
\hline \multicolumn{10}{|l|}{$\operatorname{Exp}(\%)$} \\
\hline average & 28.5 & 29.9 & 31.5 & 32.6 & 33.1 & 33.3 & 33.7 & 36.6 & 37.1 \\
\hline minimum & 7.1 & 8.1 & 8.1 & 8.0 & 7.7 & 7.4 & 7.9 & 9.0 & 8.9 \\
\hline maximum & 69.3 & 76.7 & 83.5 & 106.8 & 93.6 & 85.7 & 84.5 & 82.0 & 82.7 \\
\hline CV & 64.5 & 63.6 & 61.8 & 71.1 & 71.3 & 63.5 & 61.6 & 58.0 & 57.3 \\
\hline \multicolumn{10}{|l|}{ Gdp (\%) } \\
\hline average & -1.2 & -0.2 & -0.2 & 1.6 & 1.8 & 1.9 & 2.1 & 1.5 & \\
\hline minimum & $\begin{array}{r}-14.8 \\
95\end{array}$ & $\begin{array}{r}-14.7 \\
10\end{array}$ & -7.5 & -5.0 & -16.5 & -4.6 & -12.4 & -8.1 & -2.7 \\
\hline $\operatorname{cox}_{\mathrm{cV}}$ & $\begin{array}{r}9.5 \\
-528.8\end{array}$ & 10.2 & $\begin{array}{r}8.1 \\
-24083\end{array}$ & 8.9 & 10.4 & 182.7 & 210.0 & 8.9 & 6.2 \\
\hline \multicolumn{10}{|l|}{ Invest (\%) } \\
\hline average & 19.8 & 20.1 & 20.0 & 20.7 & 21.3 & 22.2 & 22.7 & 23.6 & 22.6 \\
\hline minimum & 8.8 & 6.1 & 10.2 & 11.6 & 3.6 & 3.4 & 1.6 & 2.9 & 2.8 \\
\hline maximum & 26.8 & 32.7 & 42.3 & 32.7 & 29.9 & 33.7 & 37.0 & 36.6 & $3 \overline{5} .5$ \\
\hline cv & 28.1 & 34.3 & 36.8 & 27.3 & 32.0 & 33.2 & 35.8 & 36.8 & 35.9 \\
\hline \multicolumn{10}{|c|}{ Tradebal (\$millions) } \\
\hline average & $1,061.6$ & $1,251.9$ & $1,297.6$ & 542.8 & -212.0 & -371.5 & -580.8 & 54.0 & 147.2 \\
\hline minimum & $4,044.2$ & $3,589.4$ & $3,459.4$ & $3,066.0$ & $4,658.4$ & $4,234.5$ & $4,855.3$ & $2,450.5$ & $3,518.4$ \\
\hline maximum & $19,168.0$ & $16,112.0$ & $10,747.0$ & $10,578.0$ & $15,239.0$ & $14,329.0$ & $10,861.0$ & $7,089.0$ & $13,756.0$ \\
\hline $\mathrm{CV}$ & 380.9 & 286.7 & 266.6 & 564.9 & $-2,197.9$ & $-1,139.8$ & -836.0 & $4,535.9$ & $2,390.4$ \\
\hline \multicolumn{10}{|c|}{ CurAcctBal (\$millions) } \\
\hline average & -378.1 & -309.5 & -59.3 & -682.7 & $-1,308.2$ & $-1,727.1$ & $-1,901.6$ & $-1,328.4$ & $-1,399.6$ \\
\hline minimum & $4,044.2$ & $3,589.4$ & $3,459.4$ & $3,066.0$ & $4,658.4$ & $4,234.5$ & $4,855.3$ & $2,450.5$ & $3,518.4$ \\
\hline maximum & $4,156.2$ & $2,161.0$ & $8,279.0$ & $\begin{array}{r}2,349.0 \\
-438.4\end{array}$ & $\begin{array}{r}6,089.0 \\
-387.6\end{array}$ & 113.1 & $2,541.0$ & $2,014.0$ & $\begin{array}{l}8,914.0 \\
-366.6\end{array}$ \\
\hline CV & & & & & & & & & \\
\hline
\end{tabular}

Note: Author's calculation from statistics compiled at http:/www.iadb.org.

Table 2 presents summary statistics by year for all countries and allows for the observation of trends in year-to-year variations. The variability in agriculture as a percentage of GDP was higher in 1994 and lower in 1990 than in any other year. Between 1988 and 1996, variability in agriculture as a percentage of GDP increased by 8.4 percent, suggesting a divergence in the contribution of agriculture to GDP across countries at the regional level. During that period, the average 
contribution of agriculture as a percentage of GDP ranged from 15.5 to 15.9 percent. In most cases, the maximum contribution of agriculture to GDP is about 20 times the minimum. These statistics provide preliminary evidence regarding the state of economic development and the importance of agriculture in that region. During the course of economic development, the contribution of agriculture to the overall economy generally decreases. In both cases, the minimum and maximum values for agriculture as a percentage of GDP increased from their initial level in 1988.

Unlike the variability in agriculture as a percentage of GDP, the variability in debt as a percentage of GDP was 48 percent lower in 1996 compared to 1988 and reflects a narrowing of differences in debt across the region. Evidence of this narrowing can be seen from the 51 percent decrease in average debt as a percentage of GDP over the 1988-1996 period. This trend is also seen in debt service ratio as a percentage of GDP and may have been helped by policy reform programs undertaken with the support of the International Monetary Fund and the World Bank (see Krueger 1993). The success of these reforms varied widely as is evident from the GDP growth rates for individual countries in Table 1.

The regional trends for GDP, and gross domestic investment, are generally favorable. For example, average GDP improved from -1.2 to 1.4 percent between 1988 and 1996, while average gross domestic investment increased by 14 percent, from 19.8 to 22.6 percent, for the same period.

\section{ECONOMETRIC MODEL SPECIFICATION}

The data for which the econometric model is specified contain observations on a cross section of countries over time and may be estimated using either fixed- or random-effects models. These models provide extra efficiency by utilizing the time series/cross section connection in the data and are usually employed when the number of cross-sectional units is large and the number of the time periods over which the units are observed is small (Kennedy 1994). There exist some guidelines regarding which model should be estimated.

Kennedy (1994) suggests that the fixed-effects model may be reasonable if the data to be analyzed contain observations on all units of the population being examined. On the other hand, if the data are a sample from a large population and inferences will be made with respect to other members of that population, then the random effects approach may be more appropriate. Such an approach assumes that the random error associated with each cross-sectional unit is uncorrelated with the other regressors, a condition that may not hold. Hausman (1978) provides a test to examine whether there exists correlation between the error term and the regressors.

The fixed-effects model is particularly appropriate in that context for two reasons. First, although it is difficult to capture all of the institutional, social, and economic factors that determine variations in growth across countries, the permanent differences between countries can be specified with the fixed-effects model. 
The institutional differences would include, for example, the framework within which many of the countries in the study embarked on policy reforms and the varying degrees of success achieved. These variations would affect economic growth. However, the degree to which the many institutional differences affect growth would best be sorted out by institutional and historical analysis at the country level, as opposed to cross-country regressions. Second, although the data set does not include the entire population of countries in Latin America and the Caribbean, the list of countries in the data set represents a significant proportion of those countries for which data are available. ${ }^{10}$

As indicated above, the fixed-effects model takes advantage of the panel structure of the data to account for variation across countries and over time. Within this framework, the effects of the cross-sectional variation and time-specific effects are captured by allowing the intercept terms of growth equations to vary across cross section units and across time. Formally, let the system of equations be represented by

$$
Y_{i t}=\alpha+\mu_{i}+\gamma_{t}+X_{k i t} \beta_{k}+\varepsilon_{i t}, i=1,2, \ldots, N ; t=1,2, \ldots, T ; k=1,2, \ldots, K,
$$

where $Y_{i t}$ the dependent variable, is a measure of growth for country $i$ in year $t$. In this model, $\alpha$ is the average intercept, $\mu_{\mathrm{i}}$ represents the difference of the mean value, $\alpha$, from the intercept corresponding to the $i^{\text {th }}$ country, and $\gamma_{t}$ represents the difference of the mean intercept, $\alpha$, from that of the $t^{\text {th }}$ period. The explanatory variable $X_{\text {kit }}$ is a vector of socioeconomic variables. The parameter $\mu_{i}$ represents the influence of the variables that vary across the cross-section of countries, but remain constant over time, while the parameter $\gamma_{t}$ represents the influence those factors that are common to all countries and change over time. The cross section effect, $\mu_{i}$, and the time effect, $\gamma_{t}$, are assumed to be fixed. In the above formulation, $\mathrm{N}$ denotes the number of cross-sectional units and $\mathrm{T}$ denotes the number of time periods. The vector of disturbances corresponding to the $i^{\text {th }}$ cross-sectional unit, $\varepsilon_{i}$ has the property $\mathrm{E}\left[\varepsilon_{\mathrm{i}}\right]=0, \mathrm{E}\left[\varepsilon_{\mathrm{i}} \varepsilon_{\mathrm{i}}^{\prime}\right]=\sigma^{2} \mathrm{I}_{\mathrm{T}}$, and $\mathrm{E}\left[\varepsilon_{\mathrm{i}} \varepsilon_{\mathrm{j}}^{\prime}\right]=0$ for $\mathrm{i} \neq \mathrm{j}$.

The assumption that the parameters $\mu_{i}$ and $\gamma_{t}$ are fixed implies that one of the $\mu_{i}$ 's and one of the $\gamma_{t}^{\prime}$ s is redundant. To address that problem and facilitate the estimation of the model using the Least Squares method, we impose the restrictions $\mu_{i}=0$ and $\gamma_{t}=0$. Thus, instead of estimating Equation 1 directly with (N-1) cross section dummies and (T-1) time-specific dummy variables, one can account for the $\mu_{\mathrm{i}}$ and $\gamma_{\mathrm{t}}$ effects by transforming the model according to the following procedure.

First, transform the dependent variable and each explanatory variable by letting

$$
\tilde{u}_{k i t}=u_{k i t}-\bar{u}_{k i .}-\bar{u}_{k . t}+\bar{u}_{k . .}
$$

10The analysis was performed using the software program LIMDEP, developed by Greene (1998). The Hausman (1978) test suggested that the null hypothesis, i.e., that there exists no correlation between the error term and the regressors, be rejected, making the fixed-effects model the more appropriate. 
where $\overline{\mathrm{u}}_{\mathrm{ki} .}=\mathrm{U}_{\mathrm{kit}}^{\mathrm{T}} / \mathrm{T}, \overline{\mathrm{u}}_{\mathrm{k.t}}=\mathrm{U}_{\mathrm{kit}}^{\mathrm{N}} / \mathrm{N}$, and $\overline{\mathrm{u}}_{\mathrm{k} . .}=\mathrm{U}_{\mathrm{kit}}^{\mathrm{NT}} / \mathrm{NT}$. Second, we use the transformed variables from Equation 2 to rewrite Equation 1 as

$$
\tilde{\mathrm{Y}}_{\mathrm{it}}=\tilde{\mathrm{X}}_{\mathrm{kit}} \beta_{\mathrm{k}}+\tilde{\varepsilon}_{\mathrm{it}}, \mathrm{i}=1,2, \ldots, \mathrm{N} ; \mathrm{t}=1,2, \ldots, \mathrm{T} ; \mathrm{k}=1,2, \ldots, \mathrm{K} .
$$

Equations 1 and 3 share the same slope coefficients but do not contain any dummy variables. Thus, one can apply the OLS procedure to Equation 3 to obtain estimates of the slope coefficients ( $\beta^{\prime}$ s).

\section{EMPIRICAL RESULTS}

The fixed-effects results of the empirical model are presented in Table 3. The dependent variable is the rate of growth of real per capita GDP. Four models were estimated to examine the influence of socioeconomic variables on growth in Latin America and the Caribbean. Socioeconomic variables were excluded or included to reflect the economic realities in the region. For example, some countries in the region benefit from very low levels of investments. This variable is excluded in model 1 to assess the potential impact on economic growth in the region.

TABLE 3

Fixed-Effects Analysis of the Influence of Parameter Estimates on Growth

\begin{tabular}{lllll}
\hline & \multicolumn{1}{c}{1} & \multicolumn{1}{c}{2} & \multicolumn{1}{c}{3} & \multicolumn{1}{c}{4} \\
\hline Agri & -0.4152 & 0.0116 & -0.1537 & -0.1428 \\
& $(1.59)$ & $(0.04)$ & $(0.56)$ & $(0.52)$ \\
Debt & $-0.0128^{*}$ & & $-0.0115^{*}$ & $-0.012^{*}$ \\
& $(2.49)$ & & $(2.25)$ & $(2.34)$ \\
Exp & $0.1883^{*}$ & $0.1875^{*}$ & $0.1655^{*}$ & $0.1503^{*}$ \\
Tradebal & $(3.55)$ & $(3.50)$ & $(3.13)$ & $(2.85)$ \\
Invest & $-0.0003^{*}$ & $-0.0002^{*}$ & $-0.0002^{*}$ & \\
Debtsvc & $(2.90)$ & $(2.09)$ & $(2.00)$ & $0.2492^{*}$ \\
& & $0.2252^{*}$ & $0.2042^{*}$ & $(3.45)$ \\
$\mathrm{R}^{2}$ adj & & $(2.96)$ & $(2.72)$ & \\
No. of observations & & -0.0095 & & \\
\hline
\end{tabular}

Note: Absolute values of the $t$-statistics are in parentheses.

*Significant at the $5 \%$ level or better.

The results are robust across specifications with little change in the explanatory power of the four models. Each model explains about 25 percent of the variation in growth. ${ }^{11}$

All the models tell a similar story with respect to the importance of agriculture and exports as a percentage of GDP to growth in Latin America and the Caribbean. The analysis reveals that agriculture as a percentage of GDP does not influence regional growth in Latin America and the Caribbean; this result is consistent with past studies. Sachs and Warner (1997) show that economic growth suffers as the proportion of primary products to total exports increases. The explanation is as follows. Developing economies generally export agricultural commodities

${ }^{11}$ In the absence of similar studies, it is difficult to make a judgement regarding the size of $R^{2}$. 
as raw materials. The export of such commodities does not create value added activities throughout the economy in the form of forward linkage effects (see Tavernier 1998). For example, although Brazil benefited from high primary commodity prices (coffee and the soybean complex-beans, meal, oil) in 1997, the industrial sector accounted for most of the increase in output because of value added in secondary sectors.

The results show that increases in exports as a percentage of GDP have a positive relationship to growth in Latin America and the Caribbean. The evolving trade patterns in the Western Hemisphere shed some light on why that might be the case. ${ }^{12}$ First, the export share of raw agricultural commodities continues to decline. Second, high-volume processed and unprocessed products increasingly account for a greater share of exports. Taken together, the first and second reasons of the evolving trade pattern suggest a greater potential for the multiplier effects to impact positively on growth. Third, virtually all countries and trading blocks have intensified efforts at diversifying exports (Valdes, Wainio, and Gehlhar 1995). ${ }^{13}$ These patterns suggest a diminished role for production agriculture in economic growth in the long run, but increasing opportunities for future economic growth in the region.

The relationship between debt as a percentage of GDP and growth is significant and negative. The result suggests that increases in debt as a percent of GDP have adversely affected growth in Latin America and the Caribbean. This problem and its relationship to more sustainable debt burdens have received considerable attention in the literature (see Cardoso and Fishlow 1990; Kaufman 1988; Ramsaran 1995). The variable that measures the debt service ratio as a percentage of GDP is negative, though not significant.

The negative sign on trade balance is interesting for what it says. The results seem to support the fact that consistent negative trade balances have been a drag on growth in Latin America and the Caribbean. Table 1 indicates that 18 of the 24 countries examined for the period 1988-1996 had negative average trade balances. These balances adversely impact the current account balances in Latin America and the Caribbean and indicate that foreign earnings from exports, tourism, and investment do not cover payments for imports and debt service. However, the negative effects of trade balances are offset by gross domestic investment. Hope (1995) argues that a high level of investment is important for a more diversified and competitive production base and increased growth. This argument is supported by the results for gross domestic investment and suggests that increases in domestic investment have a positive influence on growth.

\footnotetext{
12Because of the unfavorable international environment in 1998 (due in large measure to the Asian financial crisis), exports from the Western Hemisphere decreased by 1 percent-a consequence of a 2 percent decline from Canada, a 1 percent decline from the U.S., and a 0.9 percent decline from Latin America (IDB 1998b).

${ }^{13}$ Costa Rica is a prime example of this phenomenon. Despite a 0.9 percent decrease in exports from Latin America, Costa Rica increased its exports by approximately 20 percent because of greater export diversification and recent investments in the informatics sector by the U.S. company INTEL (IDB 1998b).
} 


\section{SUMMARY AND POLICY IMPLICATIONS}

Socioeconomic variables play an important role in economic growth in Latin America and the Caribbean. Understanding that role and its relationship to growth is a necessary condition for determining the challenges faced by developing countries in that region. Such understanding is also important for the design and implementation of policies that promote growth.

The empirical work presented in this paper is a first step in understanding the role that socioeconomic variables play in the challenges to economic growth in Latin America and the Caribbean. The study provides insights into that role and lends support to the notion that the international development community should facilitate debt reduction regimes to encourage growth in Latin America and the Caribbean. ${ }^{14}$ Such an approach is particularly important for largely agricultural economies affected by exogenous shocks, such as droughts and hurricanes, and depressed commodity prices.

The results suggest that agriculture as a percentage of GDP does not influence economic growth in Latin America and the Caribbean. This finding does not imply that agriculture has no role in the economic development of that region. Agriculture plays a significant role in providing employment and reducing poverty in rural areas in Latin America and the Caribbean (Echeverria 1999). Thus, despite the lack of significance of agriculture as a percentage of GDP, deliberate strategies to maximize the contribution that agricultural development makes in regional growth and mechanisms for programs explicitly favoring such development should simultaneously be pursued (de Janvry 1995).

With respect to exports, the empirical evidence indicates that there exists a positive relationship between exports as a percentage of GDP and economic growth in the region. Such a relationship may be capturing the beneficial impacts from the evolving trade patterns that show greater export diversification in the region. In addition, the acceleration in regional economic growth may be due to fundamental changes in economic, fiscal, and trade policy in Latin America and the Caribbean. Many of the countries in that region have removed trade barriers, liberalized investment and services policy, privatized state enterprises, and instituted important policy reforms (USTR 1997). These reforms allow resources to shift to areas of their most efficient use within those countries. However, the negative coefficient in trade balances suggests that much work remains to be done in bringing the region's trade into balance and realizing greater possible benefits from trade.

Given the high unit cost of infrastructure in developing countries, the effectiveness of investments is not always clear (McCarthy and Zanalda 1995). For Latin America and the Caribbean, the evidence shows that gross domestic investment had the greatest influence on growth in that region. This finding may be the

\footnotetext{
${ }^{14}$ This idea has equity implications. However, according to Jubilee 2000 (2001), the World Bank indicates that "without debt reduction, the debt will be perpetuated, domestic and foreign investment discouraged, and capital flight invited." Moreover, in this global trading environment highly indebted countries have less money to buy goods and services from industrialized countries, a condition that would hinder growth in those countries.
} 
result of complementarity between various industries or activities (see Corden 1997). For example, while cheap labor might be the initial motivation for an industry to relocate into a region, coordination between policy makers and industry may promote investments in human capital that could change the make up of regional production. Mexico, for example, is moving "from a mere assembler of cheap, low-quality goods, into a reliable exporter of sophisticated products, from auto brake systems to laptop computers" (Smith and Malkin 1998, p. 50).

The above results provide several useful insights into the challenges that policy makers face regarding the implications of policy decisions on growth in Latin America and the Caribbean. For now, the deleterious effects of debt and negative trade balances may be mitigated several fold by the increasingly positive roles of gross domestic investments and exports. These influences will moderate as debt increases and the erosion of commodity prices continues. The cyclical nature of such prices argues for greater efforts at pursuing a diversified exportgrowth strategy to improve trade balances and a judicious approach to borrowing and debt reduction. Moreover, attracting public and private investments in infrastructure are to be encouraged as mechanisms to facilitate growth in the region. Clearly, recent developments related to the Asian financial crisis might temper the desire of policy makers in Latin America and the Caribbean to embrace foreign direct investment. Such investment has been shown to have a positive effect on gross domestic investment. Issues related to the type of investment to be encouraged places further challenges on the policy options for increasing growth in Latin America and the Caribbean.

\section{REFERENCES}

Bernal, R.L. "Influencing U.S. Policy Toward the Caribbean: A Post Cold War Strategy." In A.T. Bryan (ed.) The Caribbean: New Dynamics in Trade and Political Economy, 209-230. New Brunswick, N.J.: Transaction Publishers, 1995.

Bush, G.H.W. "Remarks by the President in an Address to the Council of Americas Dinner." Washington, D.C., White House, April 23, 1992.

Cardoso, E., and A. Fishlow. "The Macroeconomics of the Brazilian External Debt.

In Jeffrey D. Sachs (ed.) Developing Country Debt and Economic Performance, 269-391. Chicago: University of Chicago Press, 1990.

Corden, W.M. Trade Policy and Economic Welfare. 2d ed. Oxford: Clarendon Press, 1997.

de Janvry, A. Comments to Document: "IDB's Elements of a Sustainable Agricultural and Rural Development Strategy." SDS/ENV Workshop, Washington, D.C., August 1995.

Echeverria, R.G. "Options for Rural Poverty Reduction in Latin America and the Caribbean." Paper presented at the Latin America and Caribbean Economic Association Meeting on Progress with Rural Development: New Approaches and Unresolved Issues, New York City, January 3, 1999.

Greene, W.H. LIMDEP User's Manual and Reference Guide, Version 7. Bellport, N.Y.: Econometric Software, 1998. 
Haque, B. "Trinidad and Tobago: Recent Performance, Outlook, and Statistical Profile." Available at: http://www.iadb.org/exr/sep/tt981.htm. March 1998.

Hausman, J.A. "Specification Tests in Econometrics." Econometrica 46 (1978), 1251-1271. Hope, K.R. "Recent Performance and Trends in the Caribbean Economy: A Study of Selected Caribbean Countries." In A.T. Bryan (ed.) The Caribbean: New Dynamics in Trade and Political Economy, 1-61. New Brunswick, N.J.: Transaction Publishers, 1995.

Inter-American Development Bank (IDB). Available at: http://www.iadb.org/ exr/english/Research-Data/research-data.htm. February 1998a.

"Integration and Trade in the Americas: A Preliminary Estimate of 1998 Trade." Periodic Note. Washington, D.C.: IDB, Department of Integration and Regional Programs, Division of Integration, Trade and Hemispheric Issues, Statistical and Quantitative Analysis Unit, December 1998b.

Available at: http://www.iadb.org/int/sta/ENGLISH/staweb/ latinamerica/lastats_ig_frm.htm. February 1999a.

"Brazil." Available at: http://www.iadb.org/regions/re1/sep/br/ br-sep.htm. February 1999b.

Jubilee. Available at: http://www.j2000usa.org/debt/edpac/quest.html. April 2001.

Kaufman, R. The Politics of Debt in Argentina, Brazil and Mexico. Berkeley: University of California Press, 1988.

Kennedy, P. A Guide to Econometrics. Cambridge: MIT Press, 1994, pp. 240-241.

Krueger, A. Political Economy of Policy Report in Developing Countries. Cambridge: MIT Press, 1993.

Lora, E., and F. Barrera. "A Decade of Structural Reform in Latin America: Growth, Productivity, and Investment Are Not What They Used To Be." Working Paper Green Series \#350. Washington, D.C.: IDB, Department of Research, Office of the Chief Economist, 1997.

McCarthy, F.D., and G. Zanalda. "Economic Performance in Small Open Economies: The Caribbean Experience-1980-1992." Washington, D.C.: The World Bank Office of the Vice President and Chief Economist, Development Economics Department, 1995.

McNamee, Mike, Kerry Capell, Ian Katz, Carol Matlack, and Thane Peterson. "Piece by Piece, A Financial Recovery Plan?" Business Week, 19 October 1998.

Office of the United States Trade Representative (USTR). "Future Free Trade Area

Negotiations: Report on Significant Market Opening." Wasington, D.C., May 1, 1997.

Ramsaran, R. "Challenges to Caribbean Economic Development in the 1990s." In A.T. Bryan (ed.) The Caribbean: New Dynamics in Trade and Political Economy. New Brunswick, N.J.: Transaction Publishers, 1995.

Sachs, J., and A. Warner. "Fundamental Sources of Long-Run Growth." American Economic Review 87 (1997), 184-189.

Schaffer, W. "Enterprise for the Americas Initiative Offers New Trade, Investment Opportunities." Business America 113 (1992), 2-4. 
Smith, Geri, and Elisabeth Malkin. "Mexican Makeover: NAFTA Creates the World's Newest Industrial Power." Business Week, 21 December 1998.

Tavernier, E.M. "Contribution of Regional Trading Arrangements to Economic Convergence: The Case of Latin America and the Caribbean." Paper presented at the Twenty-Third Annual Conference of the Caribbean Studies Association, St. John's Antigua, May 1998.

Templeman, John, ed. "Can Cardoso Steer Brazil Away From the Abyss?" Business Week, 23 November 1998.

United States Agency for International Development (USAID). Available at: http://www.usaid.gov/economic_growth/trdweb/viewdata. 20 June 2001. Valdes, C., J. Wainio, and M. Gehlhar. "Agricultural Trade and Economic Integration in the Western Hemisphere: Current Status." Paper presented at IATRC/IICA Symposium on Economic Integration in the Western Hemisphere, San José, Costa Rica, June 1995.

Woolley, Suzanne. "Wall Street Sizes Up 1999." Money 27, no. 13 (1998).

World Bank Group (WBG). "Latin America and the Caribbean." Available at: http://www.worldbank.org/html/extdr/offrep/lac/lacrb.htm. May 7, 1998. 
